\title{
Influence of Body Fat Distribution on Free Fatty Acid Metabolism in Obesity
}

Michael D. Jensen, Morey W. Haymond, Robert A. Rizza, Philip E. Cryer," and John M. Miles

Endocrine Research Unit, Departments of Medicine and Pediatrics, Mayo Clinic, Rochester, Minnesota 55905;

*Metabolism Division, Washington University School of Medicine, St. Louis, Missouri 63110

\begin{abstract}
In order to determine whether differences in body fat distribution result in specific abnormalities of free fatty acid (FFA) metabolism, palmitate turnover, a measure of systemic adipose tissue lipolysis, was measured in 10 women with upper body obesity, 9 women with lower body obesity, and 8 nonobese women under overnight postabsorptive (basal), epinephrine stimulated and insulin suppressed conditions. Results: Upper body obese women had greater $(P<0.005)$ basal palmitate turnover than lower body obese or nonobese women $(2.8 \pm 0.2$ vs. $2.1 \pm 0.2$ vs. $1.8 \pm 0.2 \mu \mathrm{mol} \cdot \mathrm{kg}$ lean body mass $(\mathrm{LBM})^{-1} \cdot \mathrm{min}^{-1}$, respectively), but a reduced $(P<0.05)$ net lipolytic response to epinephrine (59 \pm 7 vs. $79 \pm 5$ vs. $81 \pm 7$ $\mu \mathrm{mol}$ palmitate/kg LBM, respectively). Both types of obesity were associated with impaired suppression of FFA turnover in response to euglycemic hyperinsulinemia compared to nonobese women $(P<0.005)$. These specific differences in FFA metabolism may reflect adipocyte heterogeneity, which may in turn affect the metabolic abberations associated with different types of obesity. These findings emphasize the need to characterize obese subjects before studies.
\end{abstract}

\section{Introduction}

Plasma free fatty acids (FFA), originating from the release of adipose tissue triglyceride fatty acid, represent virtually the only route by which these fat stores can be transferred to nonfat tissue for net loss via oxidation. Free fatty acid metabolism in obesity has, therefore, been the subject of many studies over the last thirty years. Unfortunately, conflicting conclusions regarding several aspects of FFA metabolism have appeared, including the antilipolytic effectiveness of insulin in obesity (1, 2), the relationship of FFA release to the amount of body fat (3-5), and the lipolytic responsiveness of obese individuals to catecholamines (6-8). These potential differences in FFA metabolism between lean and obese humans may be of considerable importance in that they reflect either abnormalities of adipose tissue or of the body's ability to hormonally regulate adipose tissue lipolysis. Plasma FFA concentrations may not accurately reflect FFA flux (i.e., effective adipose tissue lipolysis) in obesity (9); isotope dilution studies are, therefore, necessary in order to measure lipolysis in vivo (9).

Presented in part at the Mid-western Regional (1987) and National Meetings of the American Federation for Clinical Research (1988).

Address reprint requests to Dr. Jensen, Endocrine Research Unit, Mayo Clinic, 5-164 West Joseph, Rochester, MN 55905.

Received for publication 8 June 1988 and in revised form 20 September 1988.

J. Clin. Invest.

(C) The American Society for Clinical Investigation, Inc.

$0021-9738 / 89 / 04 / 1168 / 06 \$ 2.00$

Volume 83, April 1989, 1168-1173
It is now clear that obesity is a heterogeneous disorder. Moderately obese women with waist to hip circumference ratios (WHR) ${ }^{1}$ of greater than 0.85 (upper body obesity) have an increased risk of hypertriglyceridemia, glucose intolerance, hypertension (10), and insulin resistance with regards to glucose metabolism (11), whereas women with lower body obesity (WHR less than 0.76$)(10,11)$ do not. Thus, characterization of body fat distribution is important in planning metabolic studies of obesity.

Although the relationship between adipocyte heterogeneity and metabolic complications of obesity is not clear, it is interesting to note that adipocytes from various body regions differ from one another in many respects. Fat cell size and basal lipolysis vary in adipocytes from omental, abdominal subcutaneous, and gluteal-thigh adipose tissue depots (12-14). In addition, differences in the ability of insulin to suppress lipolysis (14) and of catecholamines to stimulate lipolysis (13) are present. If these in vitro differences are reflected in vivo, abnormalities might develop which could influence the metabolic manifestations of obesity. Increased FFA flux is associated with hypertriglyceridemia (15) and failure to suppress lipolysis could result in glucose intolerance via the glucose-fatty acid cycle $(16,17)$. Thus, differences in body fat distribution, by altering the proportions of lipolytically dissimilar adipocytes, could play a role in the obesity phenotypes. The present study was undertaken to determine whether differences in body fat topography in healthy, obese women are associated with specific abnormalities of FFA metabolism.

\section{Methods}

Subjects. Informed written consent was obtained from 19 healthy, moderately obese (body mass index [BMI] $30-35 \mathrm{~kg} / \mathrm{m}^{2}$ ) premenopausal women and 8 nonobese premenopausal women. The obese women were selected such that 10 had WHR (18) of $>0.85$, and 9 had WHR $<0.76$. Subjects were free of acute or chronic illnesses and were taking no medications known to affect FFA metabolism. All women had maintained a stable weight for more than 2 mo before the study and were instructed to consume more than $200 \mathrm{~g}$ of carbohydrate daily for at least 2 wk before the study. A summary of the subjects' clinical characteristics, serum lipids, and body composition is given in Table $\mathrm{I}$.

Materials. $1-\left[{ }^{14} \mathrm{C}\right]$ Palmitate (Research Products Int. Corp., Mount Prospect, IL) was prepared for intravenous infusion as a $0.3 \%$ albumin in $0.9 \% \mathrm{NaCl}$ solution as previously described (19). $3-\left[{ }^{3} \mathrm{H}\right] \mathrm{Glucose}$ was obtained from Amersham Corp. (Arlington Heights, IL). Insulin (Actrapid Human; Squibb Novo, Inc., Princeton, NJ), epinephrine (Parke, Davis and Co., Detroit, MI), and ascorbic acid (Cevalin; Eli Lilly and Co., Indianapolis, IN) were used in the study.

Assays. Plasma palmitate concentration and specific activity were determined by a modification (20) of our previously published HPLC technique (21). Plasma FFA concentrations were determined by a

1. Abbreviations used in this paper: BMI, body mass index; LBM, lean body mass; $R_{\mathrm{a}}$, rate of appearance; $R_{\mathrm{d}}$, rate of disappearance; WHR, waist to hip circumference ratio. 


\begin{tabular}{lccccccc}
\hline & Age & $\begin{array}{c}\text { Body mass } \\
\text { index }\end{array}$ & Waist-hip ratio & Lean body mass & $\begin{array}{c}\text { Lean body } \\
\text { mass } \div \text { weight }\end{array}$ & Serum triglycerides & Serum cholesterol \\
\hline & $y r$ & $k g / m^{2}$ & & $k g$ & $\%$ & $m g / d l$ & $m / d l$ \\
$\mathrm{UB} \mathrm{Ob}(n=10)$ & $36 \pm 2$ & $32.6 \pm 0.7$ & $0.90 \pm 0.01^{\ddagger}$ & $43.4 \pm 1.1$ & $51 \pm 1$ & $145 \pm 21^{*}$ & $216 \pm 6$ \\
LB Ob $(n=9)$ & $39 \pm 2$ & $33.2 \pm 0.6$ & $0.72 \pm 0.01$ & $46.4 \pm 1.4^{\ddagger}$ & $52 \pm 1$ & $71 \pm 8$ & $209 \pm 14$ \\
Non Ob $(n=8)$ & $37 \pm 2$ & $21.9 \pm 0.7$ & $0.73 \pm 0.01$ & $41.7 \pm 1.1$ & $72 \pm 3^{*}$ & $50 \pm 6$ & $188 \pm 10$ \\
\hline
\end{tabular}

UB Ob, Upper body obese women, LB Ob, lower body obese women, Non Ob, nonobese women. Because waist to hip circumference ratios were not random variables between obese subjects, these values are not analyzed $\mathrm{UB} \mathrm{Ob}$ vs. $\mathrm{LB} \mathrm{Ob} .{ }^{*} P<0.001 \mathrm{cf}$. other groups. ${ }^{\ddagger} P<0.05$ cf. Non Ob.

microfluorometric enzymatic assay (22). Plasma insulin (23), C-peptide (24), glucagon (25), and growth hormone (26) concentrations were measured by radioimmunoassay, and plasma epinephrine and norepinephrine were measured by radioenzymatic assay (27). Plasma glucose concentrations were determined by glucose analyzer (Yellow Springs Instruments, Yellow Springs, $\mathrm{OH}$ ) and glucose specific activity was determined as previously described (28).

Protocol. Each subject underwent lean body mass (LBM) determination by tritiated water space and/or body potassium counting (29) before the studies, which were performed in the follicular phase of each woman's menstrual cycle in order to eliminate the confounding variable of changing serum estrogen concentrations (30). The subjects were admitted to the Mayo Clinic General Clinical Research Center the evening before the first study. The following morning, after an overnight fast, a 19-gauge butterfly needle was inserted into a dorsal hand vein in a retrograde fashion, and the hand was placed in a heated $\left(50-55^{\circ} \mathrm{C}\right)$ box for sampling of arterialized blood (31). An 18-gauge infusion catheter was placed in a contralateral forearm vein and kept patent by controlled infusion of $0.9 \% \mathrm{NaCl}(20 \mathrm{ml} / \mathrm{h})$. At 0800 hours $(-150 \mathrm{~min})$, an infusion of $1-\left[{ }^{14} \mathrm{C}\right]$ palmitate $(\sim 0.2 \mu \mathrm{Ci} / \mathrm{min})$, and a primed $(\sim 22 \mu \mathrm{Ci})$ continuous $(\sim 0.22 \mu \mathrm{Ci} / \mathrm{min})$ infusion of $3-\left[{ }^{3} \mathrm{H}\right]-$ glucose were begun and continued through $+60 \mathrm{~min}$. From time 0 to $60 \mathrm{~min}$, subjects received an intravenous infusion of epinephrine, diluted in $0.9 \%$ saline containing $1 \mathrm{mg} / \mathrm{ml}$ ascorbic acid (to prevent epinephrine degradation), at a rate of $17 \mathrm{ng} \cdot \mathrm{kg} \mathrm{LBM}^{-1} \cdot \mathrm{min}^{-1}$. Pulse and blood pressure were monitored on two occasions from -30 to 0 $\mathrm{min}$ and at 10-min intervals from 0 to $60 \mathrm{~min}$. The subjects returned 3 $\mathrm{d}$ later and were studied in an identical fashion, except that they received intravenous insulin $(0.14 \mathrm{mU} / \mathrm{kg} \mathrm{LBM}$ bolus and $0.20 \mathrm{mU} \cdot \mathrm{kg}$ $\mathrm{LBM}^{-1} \cdot \mathrm{min}^{-1}$ constant infusion) throughout the entire study, including the epinephrine infusion. A variable rate intravenous infusion of $50 \%$ dextrose was administered during the second study in order to maintain each subject's plasma glucose concentration at the values observed on the first study day.

Blood was sampled before starting the isotope infusions on each study day and assayed for palmitate and glucose SA to serve as background for that day. Blood samples were obtained at $-150 \mathrm{~min}$ and at 10 -min intervals from -30 to +60 min on each study day and analyzed for plasma concentrations of FFA, glucose, insulin, C-peptide, glucagon, growth hormone, epinephrine, norepinephrine, palmitate, and palmitate and glucose SA. In addition, plasma glucose concentrations were measured at 10 -min intervals throughout the second study to assist in determining the amount of dextrose to be infused in order to maintain euglycemia.

Calculations. Plasma palmitate and glucose concentrations and specific activity were constant from -30 to 0 min during both the baseline and the insulin clamp study days; therefore, steady state conditions were assumed for these study intervals. Palmitate rate of appearance $\left(R_{\mathrm{a}}\right)$ into the systemic circulation was calculated using steady state equations as previously described (21); these equations accurately estimate FFA $R_{\mathrm{a}}$ under conditions of changing plasma FFA concentrations (21).
During the epinephrine infusion, palmitate and glucose specific activity and concentrations were not constant. The lipolytic response to epinephrine was calculated by determining both the area under the curve above baseline palmitate $R_{\mathrm{a}}$ and the peak increment in palmitate $R_{\mathrm{a}}(19,21)$. During the epinephrine infusion, glucose $R_{\mathrm{a}}$ and disappearance $\left(R_{\mathrm{d}}\right)$ were calculated using nonsteady-state equations (32). These equations have been tested and found to perform reasonably well (33), even under conditions of much more abrupt perturbations in glucose $R_{\mathrm{a}}$ than those observed in the present study. The known exogenous glucose infusion rate during the insulin clamp was subtracted from the total glucose $R_{\mathrm{a}}$ over each ten minute time interval and used to calculate the endogenous glucose $R_{\mathrm{a}}$. Net additional endogenous glucose release in response to epinephrine was calculated as the area under the curve above baseline. Plasma hormone concentrations were constant during the $-30-0$-min study interval on both study days; therefore, mean values for each subject were determined and used to calculate group means.

All results were expressed as mean \pm SEM. Statistical comparisons between the same study periods among groups were performed using analysis of variance and subsequent Duncan's test. Comparisons between the same study periods on the saline control vs. the insulin clamp studies in the same group were made using a two-tailed paired Student's $t$ test, as were comparisons between one time interval and another on the same study day.

\section{Results}

\section{Subject characteristics (Tables I and II)}

Women with upper body and lower body obesity did not differ with respect to their degree of overweight, percent body fat, or total lean body mass. The mean ages of the women in the different groups was not different and their serum cholesterol concentrations were similar.

The serum triglyceride concentrations were greater in upper body obese women $(P<0.001)$ than lower body obese or nonobese women, whose concentrations were not different from each other. As anticipated, the nonobese women had less body fat $(P<0.001)$ than either group of obese women. The baseline plasma insulin and $\mathrm{C}$-peptide concentrations were significantly different $(P<0.001)$ among all three groups, with upper body obese women having the highest values for both, nonobese women having the lowest, and lower body obese women having intermediate concentrations. Plasma growth hormone concentrations were less in the upper body obese women than the nonobese women $(P<0.05)$; however, concentrations in the lower body obese women were not different than in the other groups. Plasma glucagon, epinephrine, and norepinephrine concentrations were similar among the three groups. 
Table II. Plasma Hormone Concentrations

\begin{tabular}{|c|c|c|c|c|c|c|}
\hline & Insulin & C-peptide & Glucagon & Growth hormone & Epinephrine & Norepinephrine \\
\hline & $\mu U / m l$ & $n g / m l$ & $p g / m l$ & $n g / m l$ & $p g / m l$ & $p g / m l$ \\
\hline \multicolumn{7}{|l|}{ Baseline } \\
\hline $\mathrm{UB} \mathrm{Ob}(n=10)$ & $10.9 \pm 1.4^{*}$ & $2.19 \pm 0.25^{*}$ & $255 \pm 39$ & $2.3 \pm 0.3^{\ddagger}$ & $31 \pm 7$ & $147 \pm 13$ \\
\hline $\mathrm{LB} \mathrm{Ob}(n=9)$ & $7.3 \pm 0.5^{*}$ & $1.44 \pm 0.09^{*}$ & $310 \pm 47$ & $3.2 \pm 0.5$ & $32 \pm 5$ & $131 \pm 12$ \\
\hline Non Ob $(n=8)$ & $4.5 \pm 0.3^{*}$ & $0.82 \pm 0.06^{*}$ & $225 \pm 15$ & $4.8 \pm 1.3$ & $34 \pm 5$ & $122 \pm 13$ \\
\hline \multicolumn{7}{|l|}{ Insulin clamp } \\
\hline UB Ob $(n=10)$ & $17.6 \pm 1.5^{*}$ & $2.12 \pm 0.22^{*}$ & $261 \pm 47$ & $1.5 \pm 0.2^{\ddagger}$ & $38 \pm 10$ & $171 \pm 28$ \\
\hline $\mathrm{LB} \mathrm{Ob}(n=9)$ & $11.5 \pm 0.7^{*}$ & $1.11 \pm 0.11^{\S}$ & $276 \pm 47$ & $2.1 \pm 0.7$ & $29 \pm 5$ & $133 \pm 12$ \\
\hline Non $\mathrm{Ob}(n=8)$ & $9.3 \pm 0.4^{*}$ & $0.79 \pm 0.08$ & $203 \pm 9$ & $5.3 \pm 1.5$ & $44 \pm 10$ & $141 \pm 15$ \\
\hline
\end{tabular}

${ }^{*} P<0.05$ cf. other groups same day. ${ }^{\ddagger} P<0.05$ cf. Non $O b$ same day. ${ }^{8} P<0.05$ cf. baseline.

\section{Palmitate and FFA kinetics}

Baseline palmitate and FFA kinetics (Table III). The plasma concentrations of palmitate and total FFA were not different among the three groups on the first study day. In contrast, palmitate and FFA flux were greater $(P<0.005)$ in upper body obese women than either lower body obese or nonobese women, whose flux values were similar to each other. The failure to detect significant differences in concentration among groups is likely to be the result of increased FFA clearance in obesity. The variability of FFA concentration and flux was similar within groups, excluding the possibility that greater variability in FFA concentration alone was responsible for the failure to detect significant differences in concentrations between groups.

Table III. FFA Kinetics

\begin{tabular}{|c|c|c|c|c|}
\hline & \multicolumn{4}{|c|}{ Baseline } \\
\hline & \multicolumn{2}{|c|}{ Concentration ( $\mu \mathrm{mol} /$ liter) } & \multicolumn{2}{|c|}{$\begin{array}{l}\text { Flux } \\
\left(\mu \mathrm{mol} \cdot \mathrm{kg} \mathrm{LBM}^{-1} \cdot \mathrm{min}^{-1}\right)\end{array}$} \\
\hline & Palmitate & FFA & Palmitate & FFA \\
\hline $\mathrm{UB} \mathrm{Ob}(n=10)$ & $128 \pm 8$ & $579 \pm 44$ & $2.8 \pm 0.2^{*}$ & $12.4 \pm 1.1^{*}$ \\
\hline $\mathrm{LB} \mathrm{Ob}(n=9)$ & $106 \pm 14$ & $412 \pm 95$ & $2.1 \pm 0.2$ & $7.8 \pm 1.5$ \\
\hline \multirow[t]{2}{*}{ Non Ob $(n=8)$} & $111 \pm 12$ & $449 \pm 73$ & $1.8 \pm 0.2$ & $7.1 \pm 1.0$ \\
\hline & \multicolumn{4}{|c|}{ Insulin clamp } \\
\hline $\mathrm{UB} \mathrm{Ob}(n=10)$ & $67 \pm 9 \ddagger$ & $297 \pm 30^{\ddagger}$ & $1.9 \pm 0.2^{\ddagger}$ & $8.5 \pm 0.9^{\ddagger}$ \\
\hline $\operatorname{LB~Ob}(n=9)$ & $63 \pm 14^{\ddagger}$ & $235 \pm 53^{\ddagger}$ & $1.6 \pm 0.2^{\ddagger}$ & $6.1 \pm 1.1^{\ddagger}$ \\
\hline \multirow[t]{4}{*}{ Non Ob $(n=8)$} & $26 \pm 4^{* \neq}$ & $118 \pm 21^{* \neq}$ & $0.8 \pm 0.1^{\text {* }}$ & $3.5 \pm 0.6^{* \neq}$ \\
\hline & \multicolumn{4}{|c|}{ Epinephrine response } \\
\hline & \multicolumn{2}{|c|}{$\begin{array}{c}\text { Area under curve } \\
\text { ( } \mu \mathrm{mol} \text { palmitate } / \mathrm{kg} \text { LBM) }\end{array}$} & \multicolumn{2}{|c|}{ 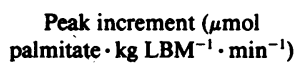 } \\
\hline & Baseline & $\begin{array}{l}\text { Insulin } \\
\text { clamp }\end{array}$ & Baseline & $\begin{array}{l}\text { Insulin } \\
\text { clamp }\end{array}$ \\
\hline $\mathrm{UB} \mathrm{Ob}(n=10)$ & $59 \pm 7^{*}$ & $54 \pm 10$ & $1.5 \pm 0.2^{\S}$ & $1.3 \pm 0.2$ \\
\hline LB Ob $(n=9)$ & $79 \pm 5$ & $74 \pm 11$ & $1.9 \pm 0.1$ & $1.7 \pm 0.2$ \\
\hline Non $\mathrm{Ob}(n=8)$ & $81 \pm 7$ & $76 \pm 8$ & $2.4 \pm 0.3$ & $2.0 \pm 0.3$ \\
\hline
\end{tabular}

* $P<0.05$ cf. other groups same day.

$P<0.05$ cf. Non Ob same day.

${ }^{\ddagger} P<0.005$ cf. baseline.
Response of palmitate and FFA kinetics to euglycemic hyperinsulinemia (Tables II to III). When plasma insulin concentrations were increased by 4-7 $\mu \mathrm{U} / \mathrm{ml}$ (Table II) during the insulin clamp, a significant $(P<0.01)$ reduction in plasma palmitate concentrations and flux occurred in all groups when compared to the baseline study. Plasma palmitate and FFA concentrations and flux during the insulin clamp were less $(P$ $<0.005$ ) in the nonobese women than either group of obese women.

Response to epinephrine (Table III, Fig. 1-3). During the epinephrine infusion on the first study day, the mean plasma insulin (Fig. 1) and C-peptide concentrations increased slightly (4.5 to $5.8 \mu \mathrm{U} / \mathrm{ml}$, and 0.81 to $0.97 \mathrm{ng} / \mathrm{ml}$, respectively, both $P$ $<0.001)$ in the nonobese women, but were unchanged in either group of obese women. The mean plasma epinephrine and norepinephrine concentrations during the baseline study epinephrine infusion were $208 \pm 24,196 \pm 14$, and $190 \pm 14$ $\mathrm{pg} / \mathrm{ml}(P=\mathrm{NS})$ and $182 \pm 17,180 \pm 18$, and $166 \pm 13 \mathrm{pg} / \mathrm{ml}(P$ $=\mathrm{NS}$ ) in upper body obese, lower body obese, and nonobese women, respectively. The intravenous epinephrine infusion during the insulin clamp study resulted in plasma epinephrine and norepinephrine concentrations of $205 \pm 27,186 \pm 11$, and $185 \pm 14 \mathrm{pg} / \mathrm{ml}(P=\mathrm{NS})$ and $184 \pm 14,182 \pm 16$, and $177 \pm 14$ $\mathrm{pg} / \mathrm{ml}(P=\mathrm{NS})$, in upper body obese, lower body obese, and nonobese women, respectively. Plasma glucagon and growth hormone concentrations did not change in response to epinephrine. Upper body obese, lower body obese, and nonobese women did not differ with regards to the peak increment responses of pulse $(+13 \pm 1$ vs. $+9 \pm 1$ vs. $+12 \pm 2 \mathrm{bpm}$, respectively), systolic $(+11 \pm 2$ vs. $+5 \pm 4$ vs. $+5 \pm 2 \mathrm{mmHg}$, respec-

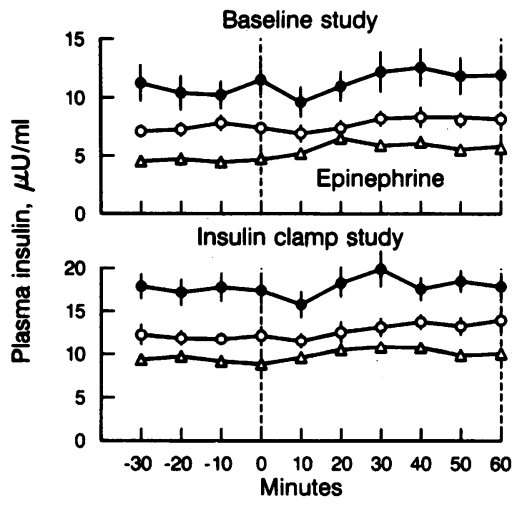

Figure 1. Plasma insulin concentrations of upper body obese, lower body obese and nonobese women before and during epinephrine infusion. $\bullet$, UB Ob $(n=10)$; O, LB $\mathrm{Ob}(n=9) ; \Delta$, Non $\mathrm{Ob}$ $(n=8)$. 


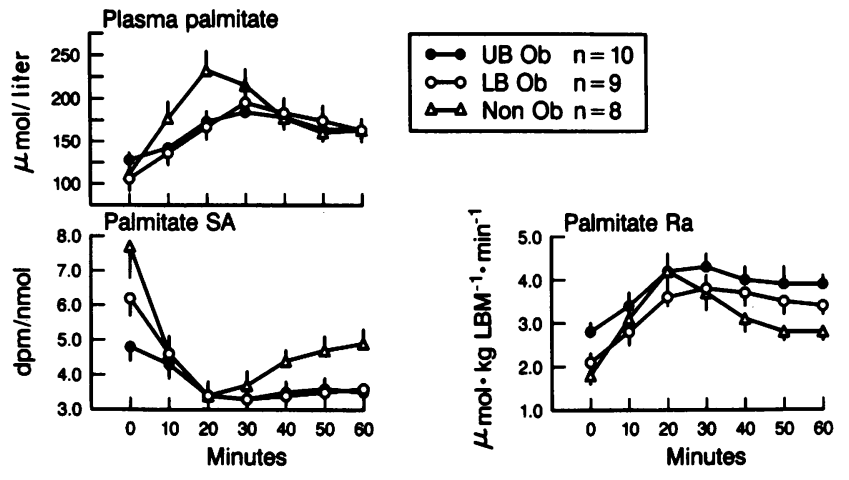

Figure 2. Palmitate kinetics during epinephrine infusion in upper body obese, lower body obese, and nonobese women.

tively) or diastolic ( $+3 \pm 1$ vs. $+1 \pm 2$ vs. $0 \pm 2 \mathrm{~mm} \mathrm{Hg}$, respectively) blood pressure.

During the baseline epinephrine infusion, plasma palmitate, and total FFA concentrations increased, palmitate SA decreased, and palmitate $R_{\mathrm{a}}$ increased in all subjects (Fig. 2). Upper body obese women had a reduced $(P<0.05)$ lipolytic response (area under the curve above baseline palmitate rate of appearance) to epinephrine when compared with those of the lower body obese or nonobese women, whose responses did not differ. The peak increment in palmitate $R_{\mathrm{a}}$ in response to epinephrine was less $(P<0.05)$ in upper body obese women than nonobese women, while the response in lower body obese women was not significantly different from either of the other groups. The lipolytic responses to epinephrine infusion during the insulin clamp study (Fig. 3) were slightly, but not significantly less in each group of women than during the baseline epinephrine infusion (Fig. 2).

Glucose kinetics (Table IV, Figs. 4 and 5). Baseline plasma glucose concentrations and flux were not different among the three groups of women. During the insulin clamp study, despite significantly lower plasma insulin concentrations, the nonobese women were found to have greater glucose utilization and less endogenous glucose production than either group of obese women (both $P<0.05$ ).

Intravenous epinephrine resulted in an increase in plasma glucose concentrations on the first study day, which were matched during the epinephrine infusion on the insulin clamp study day (Fig. 4) by carefully adjusting the exogenous glucose infusion rate. The net additional endogenous glucose release in
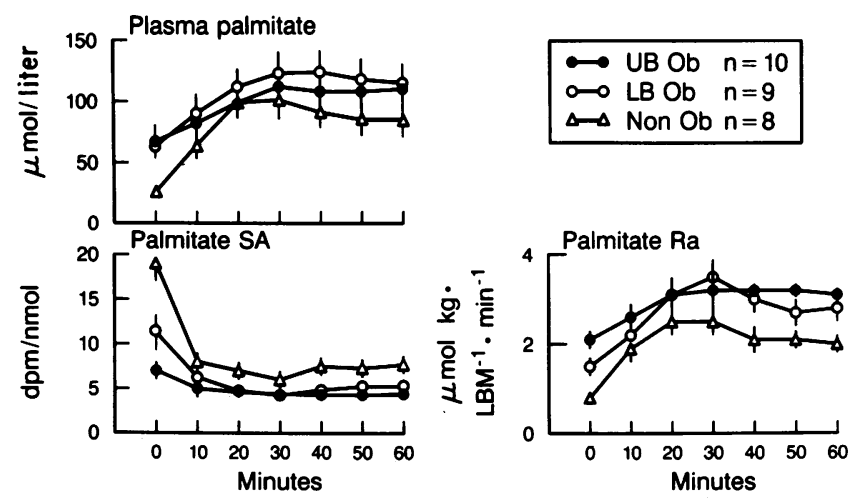

Figure 3. Palmitate kinetics during epinephrine and insulin infusions in upper body obese, lower body obese, and nonobese women.
Table IV. Glucose Kinetics

\begin{tabular}{|c|c|c|c|c|}
\hline & Glucose & \multicolumn{2}{|l|}{ Flux } & $\begin{array}{l}\text { et endogenous } R_{\mathrm{a}} \\
\text { response to } \\
\text { epinephrine }\end{array}$ \\
\hline & $m g / d l$ & \multicolumn{2}{|c|}{$m g \cdot k g L B M^{-1} \cdot \min ^{-1}$} & $m g / k g L B M$ \\
\hline \multicolumn{5}{|l|}{ Baseline } \\
\hline $\mathrm{UB} \mathrm{Ob}(n=10)$ & $94 \pm 2$ & $2.9 \pm 0.1$ & & $6.7 \pm 4.9$ \\
\hline $\mathrm{LB} \mathrm{Ob}(n=9)$ & $93 \pm 1$ & $3.0 \pm 0.1$ & & $18.1 \pm 2.4$ \\
\hline \multirow[t]{2}{*}{ Non $\mathrm{Ob}(n=8)$} & $94 \pm 1$ & $3.0 \pm 0.1$ & & $12.0 \pm 3.2$ \\
\hline & & \multicolumn{3}{|c|}{$\begin{array}{l}\text { Endogenous } \\
\text { glucose } \\
\text { production }\end{array}$} \\
\hline \multicolumn{5}{|l|}{ Insulin clamp } \\
\hline $\mathrm{UB} \mathrm{Ob}(n=10)$ & $93 \pm 2$ & $3.2 \pm 0.1^{*}$ & $2.0 \pm 0.1$ & $7.0 \pm 3.2$ \\
\hline $\mathrm{LB} \mathrm{Ob}(n=9)$ & $93 \pm 1$ & $3.2 \pm 0.1^{*}$ & $1.9 \pm 0.3$ & $11.5 \pm 7.0$ \\
\hline Non $\mathrm{Ob}(n=8)$ & $93 \pm 1$ & $3.5 \pm 0.1^{* \ddagger}$ & $1.2 \pm 0.2^{\ddagger}$ & $12.1 \pm 4.4$ \\
\hline
\end{tabular}

${ }^{*} P<0.05$ cf. baseline.

${ }^{\ddagger} P<0.05$ cf. other groups same day.

response to epinephrine (Fig. 5) was highly variable and not significantly different $(P=0.11)$ between the three groups of women. Euglycemic hyperinsulinemia did not affect the net additional endogenous glucose response to epinephrine (Fig. 5, Table IV).

\section{Discussion}

These studies demonstrate, for the first time, that in healthy, age-matched, moderately obese women, body fat topography is predictive of specific abnormalities in FFA metabolism. Despite the absence of differences in postabsorptive glucose transport, upper body obese women, but not lower body obese women had increased adipose tissue FFA release relative to lean body mass. Mild hyperinsulinemia resulted in less complete suppression of lipolysis in both types of obese women, and intravenous epinephrine resulted in a reduced net lipolytic response only in upper body obese women. Plasma palmitate and FFA concentrations alone did not distinguish the extent of the differences between these two groups of women; only by measuring FFA turnover could these abnormalities be detected.

The magnitude of the differences in FFA flux between these three groups of women is considerable. If the basal FFA flux values are viewed in the context of the potential calories

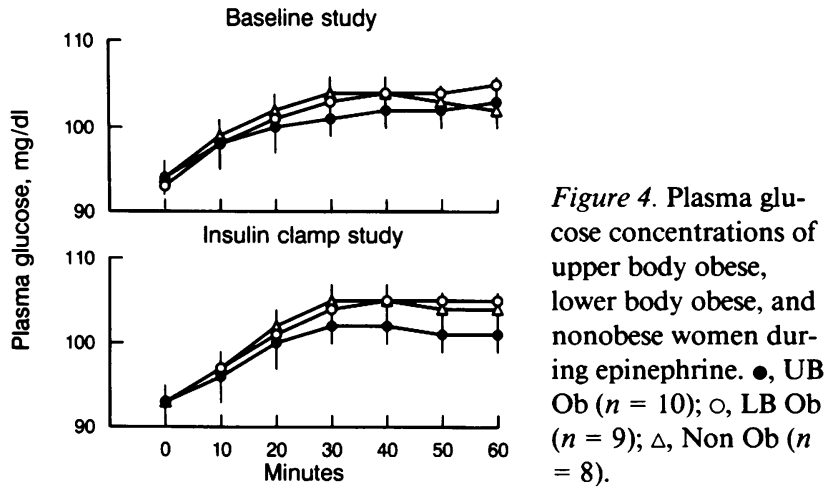




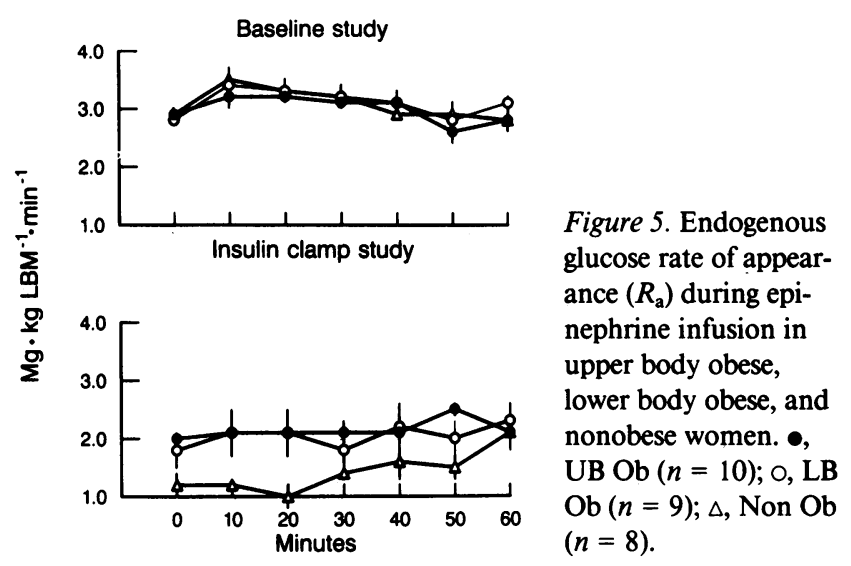

available, upper body obese women were releasing $\sim 41 \mathrm{kcal} /$ kg LBM per d, whereas lower body obese and nonobese women were releasing $\sim 26$ and $24 \mathrm{kcal} / \mathrm{kg}$ LBM per d, respectively. The former value is greater than the predicted resting energy expenditure for women $(29,34)$, whereas the latter values are $\sim 70 \%$ of resting energy expenditure for women.

Postabsorptive FFA flux has been reported to correlate positively (3), weakly (4), or not at all (5), with increasing amounts and percentages of body fat. The present study offers a possible explanation for the discrepancies between previous studies. Upper body obesity may result in increased lipolysis with increasing body fat, whereas lower body obesity does not appear to show this trend. Thus, the anthropomorphic characterization criteria proposed by Kissebah et al. (18), shown to be a predictor of differences in glucose metabolism, also predict differences in FFA metabolism.

The finding of greater FFA release from fat relative to lean tissue in upper body obese women is consistent with published reports (3), and suggests that the majority of obese individuals in those studies may have had upper body obesity. Whether the greater resting FFA flux present in this type of obesity is due to generalized or localized abnormalities of adipose tissue lipolysis is unknown. Regional differences in adipose tissue cellularity (35), fat cell size (36), and lipolysis (12-14) are known to occur in obese and nonobese humans. Increasing fat cell size is associated with increased basal lipolysis (13), and upper body obesity may be a form of "hypertrophic" obesity (36), with uniformly enlarged and lipolytically active adipocytes. Conversely, lower body obesity may be a "hyperplastic" form (36), with most fat cells having normal size and basal lipolysis. The increase in fat cell size in upper body obese women, however, occurs primarily in the abdominal subcutaneous region (18), suggesting that differences in regional adipose tissue depots may be responsible for the differences in systemic lipolysis.

Small increments in plasma insulin concentrations in these subjects resulted in marked suppression of palmitate flux, attesting to the sensitivity of lipolysis to insulin $(1,2,19)$. Note that palmitate flux remained greater in both groups of obese women than in nonobese women despite significantly greater plasma insulin concentrations. These findings are consistent with the demonstration that, in the presence of insulin, more glycerol is released from adipocytes obtained from obese than nonobese individuals (37). The accelerated lipolysis despite hyperinsulinemia could contribute to the reduced glucose uptake in obese women compared with nonobese women via the glucose-fatty acid cycle $(16,17)$.
Increased FFA availability is necessary for optimal metabolic function in situations such as fasting (39) and exercise (40). Intravenous epinephrine infusions have been used to test for defects in the ability of obese persons to enhance lipolysis (6-8), however, conflicting findings have been reported (6-8). In this study, the lipolytic response to epinephrine was reduced in upper body obese women compared with lower body obese and nonobese women. This difference could explain the discrepancies between the previous reports. The reduced lipolytic effect of epinephrine in upper body obese women is not due to generalized hyporesponsiveness to catecholamines, because increases in blood pressure, pulse, and hepatic glucose release in this group were not different than those observed in the other two groups. This abnormality in upper body obese women is consistent with in vitro studies using subcutaneous abdominal adipose tissue; adipocytes from upper body obese women increased lipolysis only $34 \%$ in response to epinephrine compared with a $139 \%$ increase in fat cells from lower body obese women (18). If this reduced ability to enhance lipolysis extends to circumstances such as caloric restriction (38) or exercise (3), this abnormality could affect treatment approaches for upper body obese individuals. Further studies are needed to answer these questions.

Although most investigators normalize FFA flux values to lean body mass $(3-5,38)$, the tissues most likely to be consuming FFA as a metabolic fuel, it should be acknowledged that alternative modes of data presentation have been chosen (38). In the present study, upper body obese women had greater basal FFA flux than lower body obese women (data not shown), whether expressed in terms of total body weight $\left(1.5 \pm 0.1\right.$ vs. $1.1 \pm 0.1 \mu \mathrm{mol}$ palmitate $\cdot \mathrm{kg}^{-1} \cdot \mathrm{min}^{-1}$, respectively, $P<0.05)$ or fat mass $(3.0 \pm 0.2$ vs. $2.3 \pm 0.2 \mu \mathrm{mol}$ palmitate $\cdot \mathrm{kg}$ fat mass ${ }^{-1} \cdot \mathrm{min}^{-1}$, respectively, $P<0.05$ ). Thus, differences in regulation of adipose tissue lipolysis between these two types of human obesity are evident independent of the method of data analysis.

In summary, the basal release of FFA from adipose tissue to meet lean body mass energy needs is greater in upper body obese women than lower body obese or nonobese women. In addition, small increments in plasma insulin concentration obtained using the euglycemic clamp technique resulted in significantly lower FFA flux in nonobese women compared with obese women, and this was associated with greater glucose disposal and lower endogenous glucose production in the nonobese women. The net lipolytic response to epinephrine is reduced in upper body obese women compared with lower body obese and nonobese women. Some of these observed differences are consistent with in vitro data regarding the regional differences in adipocyte kinetics. Our results may explain many of the conflicting reports in the literature regarding FFA metabolism in human obesity and emphasize the need to characterize the type of obesity being studied before investigations of FFA metabolism in humans.

\section{Acknowledgments}

We are indebted to M. Ellman, V. Heiling, J. Aikens, J. King, M. Persson, and S. Shah for technical assistance, and to K. Young for help in preparing the manuscript.

Supported by grants DK-38029, DK-26989, DK-29953, DK-27085, DK-20579, RR-00035, and RR-0585 from the U. S. Public Health Service and by the Mayo Foundation. 


\section{References}

1. Howard, B. V., I. Klimes, B. Vasquez, D. Brady, M. Nagulesparan, and R. H. Unger. 1984. The antilipolytic action of insulin in obese subjects with resistance to its glucoregulatory action. J. Clin. Endocrinol. Metab. 58:544-548.

2. Golay, A., A. L. M. Swislocki, Y.-D. I. Chen, J. B. Jaspan, and G. M. Reaven. 1986. Effect of obesity on ambient plasma glucose, free fatty acid, insulin, growth hormone, and glucagon concentrations. $J$. Clin. Endocrinol. Metab. 63:341-484.

3. Björntorp, P., H. Bergman, and E. Varnauskas. 1969. Plasma free fatty acid turnover rate in obesity. Acta Med. Scand. 185:351-356.

4. Björntorp, P., H. Berginan, E. Varnauskas, and B. Lindholm. 1969. Lipid mobilization in relation to body composition in man. Metab. Clin. Exp. 18:840-851.

5. Lillioja, S., C. Bogardus, D. M. Mott, A. L. Kennedy, W. C. Knowler, and B. V. Howard. 1985. Relationship between insulin-mediated glucose disposal and lipid metabolism in man. J. Clin. Invest. 75:1106-1115.

6. Orth, R. D., and R. H. Williams. 1960. Response of plasma NEFA levels to epinephrine infusions in normal and obese women. Proc. Soc. Exp. Biol. Med. 104:119-120.

7. Mautalen, C., and R. W. Smith, Jr. 1965. Effects of triiodothyronine and thyroxine on the lipolytic action of epinephrine in markedly obese subjects. Am. J. Clin. Nutr. 16:363-369.

8. Balasse, E. 1968. Influence of norepinephrine, growth hormone and fasting on FFA mobilization and glucose metabolism in lean and obese subjects. Diabetologia. 4:20-25.

9. Nestel, P. J., T. Ishikawa, and R. B. Goldrick. 1978. Diminished plasma free fatty acid clearance in obese subjects. Metab. Clin. Exp. 27:589-597.

10. Evans, D. J., R. G. Hoffmann, R. K. Kalkhoff, and A. H. Kissebah. 1984. Relationship of body fat topography to insulin sensitivity and metabolic profiles in premenopausal women. Metab. Clin. Exp. 33:68-75.

11. Evans, D. J., R. Murray, and A. H. Kissebah. 1984. Relationship between skeletal muscle, insulin resistance, insulin-mediated glucose disposal, and insulin binding. J. Clin. Invest. 74:1515-1525.

12. Smith, U., J. Hammarsten, P. Björntorp, and J. Kral. 1979. Regional differences and effect of weight reduction on human fat cell metabolism. Eur. J. Clin. Invest. 9:327-334.

13. Goldrick, R. B., and G. M. McLoughlin. 1970. Lipolysis and lipogenesis from glucose in human fat cells of different sizes. Effects of insulin, epinephrine, and theophylline. J. Clin. Invest. 49:1213-1223.

14. Bolinder, J., L. Kager, J. Östman, and P. Arner. 1983. Differences at the receptor and postreceptor levels between human omental and subcutaneous adipose tissue in the action of insulin on lipolysis. Diabetes. 32:117-123.

15. Kissebah, A. J., S. Alfarsi, P. W. Adans, and W. Wynn. 1976. Role of insulin resistance in adipose tissue and liver in the pathogenesis of endogenous hypertriglycerdiemia in man. Diabetologia. 12:563571.

16. Randle, P. J., P. B. Garland, C. N. Hales, and E. A. Newsholme. 1963. The glucose-fatty acid cycle; its role in insulin sensitivity and the metabolic dis-turbances of diabetes mellitus. Lancet. i:785-789.

17. Ferrannini, E., E. J. Barrett, S. Bevilacqua, and R. A. DeFronzo. 1983. Effect of fatty acids on glucose production and utilization in man. J. Clin. Invest. 72:1737-1747.

18. Kissebah, A. H., N. Vydelinqum, R. Murray, D. J. Evans, A. J. Hartz, R. K. Kalkhoff, and P. W. Adams. 1982. Relation of body fat distribution to metabolic complications of obesity. J. Clin. Endocrinol. Metab. 54:254-260.

19. Jensen, M. D., M. W. Haymond, J. E. Gerich, P. E. Cryer, and J. M. Miles. 1987. Lipolysis during fasting: decreased suppression by insulin and increased stimulation by epinephrine. J. Clin. Invest. 87:207-213.

20. Jensen, M. D., P. J. Rogers, M. G. Ellman, and J. M. Miles.
1988. Choice of infusion sampling mode for tracer studies of free fatty acid metabolism. Am. J. Physiol. 17:E562-E565.

21. Miles, J. M., M. G. Ellman, K. L. McClean, and M. D. Jensen. 1987. Validation of a new method for determination of free fatty acid turnover. Am. J. Physiol. 252:E431-E438.

22. Miles, J., R. Glasscock, J. Aikens, J. Gerich, and M. Haymond. 1983. A microfluorometric method for the determination of free fatty acids in plasma. J. Lipid Res. 24:96-99.

23. Herbert, V., K. S. Lav, G. W. Gottlieb, and S. J. Bleicher. 1965. Coated-charcoal immunoassay of insulin. J. Clin. Endocrinol. Metab. 25:1375-1384.

24. Faber, O., C. Binder, J. Markussen, L. Heding, V. Naithani, H. Kuzuya, P. Blix, D. L. Horwitz, and A. H. Rubenstein. 1978. Characterization of seven C-peptide antisera. Diabetes. 27(Suppl. 1):170-177.

25. Faloona, G., and R. H. Unger. 1974. Glucagon. In Methods of Hormone Radioimmunoassay. B. Jaffe and H. Behrman, editors. Academic Press, Inc., New York. 317-330.

26. Peake, G. T. 1974. Growth hormone. In Methods of Hormone Radioimmunoassay. B. Jaffe and H. Behrman, editors. Academic Press, New York. 103-121.

27. Shah, S. D., W. E. Clutter, and P. E. Cryer. 1985. External and internal standards in the single isotope derivative (radioenzymatic) assay of plasma norepinephrine and epinephrine in normal humans and persons with diabetes mellitus or chronic renal failure. J. Lab. Clin. Med. 106:624-629.

28. Rizza, R., J. Miles, C. Verdonk, F. J. Service, and J. Gerich. 1979. Effect of intermittent endogeous hyperglucagonemia on glucose homeostasis in normal and diabetic man. J. Clin. Invest. 63:11191123.

29. Jensen, M. D., J. S. Braun, R. J. Vetter, and H. M. Marsh. 1988. Measurement of body potassium with a whole-body counter: relationship between lean body mass and resting energy expenditure. Mayo Clin. Proc. 63:864-888.

30. Morrow, P. J., W. P. Marshall, H. J. Kim, and R. K. Kalkhoff. 1981. Metabolic response to starvation. II. Effects of sex steroid administration to pre- and postmenopausal women. Metab. Clin. Exp. 30:274-278.

31. Abumrad, N. N., D. Rabin, M. P. Diamond, and W. W. Lacy. 1981. Use of a heated superficial hand vein as an alternative site for measurements of amino acid concentrations and for the study of glucose and alanine kinetics in man. Metab. Clin. Exp. 30:936-940.

32. Steele, R. 1959. Influences of glucose loading and of injected insulin on hepatic glucose output. Ann. NY Acad. Sci. 82:420-430.

33. Radziuk, J., K. H. Norwich, and M. Vranic. 1978. Experimental validation of measurements of glucose turnover in nonsteady-state. Am. J. Physiol. 3:E84-E93.

34. Ravussin, E., S. Lillioja, T. E. Anderson, L. Christin, and C. Bogardus. 1986. Determinants of 24-hour energy expenditure in man: methods and results using a respiratory chamber. J. Clin. Invest. 78:1568-1578.

35. Krotkiewski, M., P. Björntorp, L. Sjöström, and U. Smith 1983. Impact of obesity on metabolism in men and women. $J$. Clin Invest. 72:1150-1162.

36. Björntorp, P., and L. Sjöström. 1971. Number and size of adipose tissue fat cells in relation to metabolism in human obesity. Metab. Clin. Exp. 20:703-713.

37. Pedersen, O., E. Hjollund, and N. Schwart Sorensen. 1982. Insulin receptor binding and insulin action in human fat cells: effects of obesity and fasting. Metab. Clin. Exp. 31:884-895.

38. Wolfe, R. R., E. J. Peters, S. Klein, O. B. Holland, J. Rosenblatt, and H. Gary, Jr. 1987. Effect of short-term fasting on lipolytic responsiveness in normal and obese human subjects. Am. J. Physiol. 252:E189-E196.

39. Cahill, G. F., Jr. 1970. Starvation in man. N. Engl. J. Med. 282:668-675.

40. Havel, R. J., A. Naimark, and C. F. Borchgrevink. 1963. Turnover rate and oxidation of free fatty acids of blood plasma in man during exercise: studies during continuous infusion of palmitate-1-C $\mathrm{C}^{14}$. J. Clin. Invest. 42:1054-1063. 